\title{
STRATIGRAPHY AND PALEOECOLOGY OF THE MULEGE EMBAYMENT, BAJA CALIFORNIA SUR, MEXICO
}

\section{ESTRATIGRAFIA Y PALEOECOLOGIA DE LA ENSENADA DE MULEGE, BAJA CALIFORNIA SUR, MEXICO}

\author{
James R. Ashby * \\ John A. Minch** \\ *Department of Geological Sciences \\ San Diego State University \\ San Diego, CA 92182 \\ **Department of Geology \\ Saddleback College \\ Mission Viejo, CA 92692
}

Ashby James, R. and Minch, A.J. Stratigraphy and Paleoecology of the Mulegé embayment, Baja California Sur, México.Estratigrafía y paleoecolog ía de la ensenada de Mulegé, Baja California Sur, México.Ciencias Marinas Vol. 13(2): 89-112

\begin{abstract}
A diverse fauna consisting of 86 species of gastropods, 62 pelecypods, 3 echinoids, 1 scaphapod, 1 anthozoan and 1 arthropod was collected from a prominent $+12 \mathrm{~m}$ marine terrace in the Mulegé area. This fauna and two U 234/Th 230 dates of $124,000 \pm 6000$ years and $144,000 \pm$ 7000 years (Sangamon, 5e highstand) establish a late Pleistocene age for this terrace at Mulegé, Baja California Sur, México.

The geology of Mulegé area consists of a thick series of volcanoclastic rocks of the Oligocene-MioceneComondú Group unconformably overlain by thin upper Pliocene near-shore and estuarine marine sediments of the Infierno Formation. These are unconformably overlain by the Mulegé Formation (new formation) which consists of marine sandstones and conglomerates in locally extensive terrace deposits. In the late Pleistocene the Mulegé area consisted of a brackish sand and mud-flat estuary flanked by open-ocean, rocky, and sandy shoreline environments. The estuarine and near-shore environments in the Infierno Formation and Mulegé Formation document the presence of the Mulegé estuary during the late Pliocene and late Pleistocene. The presence of these paleo-environments near their original sea level position indicates no significant late Pliocene to recent uplift of the Baja California Peninsula in this area.
\end{abstract}

\section{RESUMEN}

Se colectó fauna consistente de 86 especies de gastrópodos, 63 pelecípodos, tres equinodermos, un escapópodo, un antozoario y un artrópodo de una terraza marina prominente $+12 \mathrm{~m}$ en el área de Mulegé. Se estableció una edad de Pleistoceno tardío con esta fauna y con dos dataciones de U 234/Th 230 de 124,000 \pm 6000 años y 144,000 \pm 7000 años (Sangamoniano, 5e alto marino) para esta terraza en Mulegé, Baja California Sur, México. 
La geología del área de Mulegé consiste de una serie de rocas volcanoclásticas del Oligoceno-Mioceno del Grupo Comondú con una superposición en discordancia de sedimentos marinos costeros y estuarinos del Ptioceno superior de la Formación Infierno. Están en discordancia bajo la Formación Mulegé (nueva formación) que consiste de areniscas marinas y conglomerados en depósitos extensivos de terrazas locales. En el Pleistoceno tardío el área de Mulegé consistió de arenisca marina y bajos de lodos estuarinos flanquados por el océano abierto, medios ambientes litorales rocosos y arenosos. Los ambientes estuarinosy litorales de la Formación Infierno y de la Formación Mulegé demuestran la presencia del estuario de Mulegé durante el Plioceno tardío y el Pleistoceno tardío. La presencia de estos paleoambientes cercanos a su posición original con respecto al nivel del mar indican que no ha existido un levantamiento de la Península de Baja California desde el Plioceno Tardío al reciente.

\section{INTRODUCTION}

Mulegé is located at the north end of Concepción Bay, on the eastern shore of the Baja California peninsula (111059'W longitude, 26053'N latitude, Fig. 1). The fossiliferous Pleistocene terrace localities occur around the Mulegé estuary.

\section{Previous studies}

William Gabb (1867, in Browne 1869) published the first geological reconnaissance report on the area, briefly discussing the geology of Concepción Bay. In a 1921 pack train reconnaissance, Carl H. Beal (1948) briefly mentioned the terraces and mapped the volcanics in the area of Concepción Bay as part of his Comondú Formation.

McFall (1968), provided the most detailed geologic work in the area with his reconnaissance map of the Concepcion Bay and Mulegé area. He mapped and assigned a Pleistocene age to the terraces surrounding Concepción Bay. McFall also mapped and described the underlying Pliocene rocks which he tentatively correlated, on the basis of lithology, with upper Pliocene sandstones of the Infierno Formation exposed in the Santa Rosalía area.

In his reconnaissance of the Quaternary marine terraces of central Baja California, Ortleib (1978) discussed the presence of terraces at $+9 \mathrm{~m}$ and $+12 \mathrm{~m}$ above sea level in Mulegé. He indicated these terraces were probably Sangamon in age, and that they formed as a result of transgressions and regressions during late Pleistocene time. He

\section{INTRODUCCION}

Mulegé se localiza en el extremo norte de Bahía Concepción, en la costa este de la Península de Baja California (1110 59' de longitud Oeste, 260 53' de latitud Norte, Fig.1). Las localidades de la terraza fosilifera del Pleistoceno se encuentran alrededor del estuario de Mulegé.

\section{Estudios previos}

El primer reporte de reconocimiento geológico del área fue publicado por William Gabb (1867, en Browne, 1869), discutiendo brevemente la geología de Bahía Concepción. En un reconocimientogeneral en 1921, Carl H. Beal (1948) menciona brevemente las terrazas y traza en un mapa los volcanes en el área de Bahía Concepción, como parte de su Formación Comondú.

McFall (1968), proporciona el trabajo geológico más detallado en el área con su mapa de reconocimiento geológico de Bahía Concepción y área de Mulegé. Realiza el mapa y asigna la edad Pleistoceno a las terrazas que rodean a Bahía Concepción. También realiza el mapa y describe las rocas subyacentes al Plioceno que tentativamente correlaciona en base a la litología, con las areniscas del Plioceno de la Formación Infierno expuestas en el área de Santa Rosalía.

En el reconocimiento de las terrazas marinas del Cuaternario de la porción central de Baja California, Ortleib (1978) discute la presencia de terrazas a $+9 \mathrm{~m}$ y $+12 \mathrm{~m}$ sobre el nivel del mar en Mulegé. Indica que estas terrazas probablemente pertenecen al Sanga- 
also indicated abundant fossils were to be found on the terrace at $+12 \mathrm{~m}$ and that the terrace at $+9 \mathrm{~m}$ was poorly developed and contained few fossils.

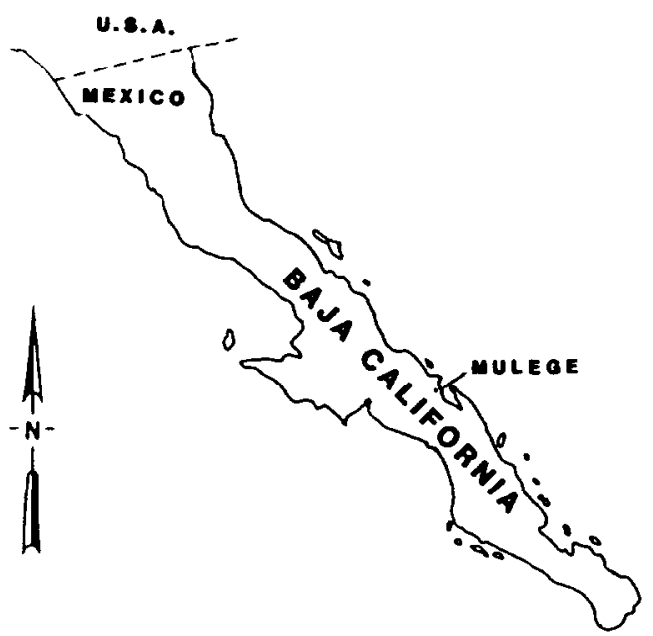

Figure 1. Localization of the study area. Figura 1. Localización del área de studio.

\section{Present Work}

Field work for this report was undertaken between 1977 and 1983. The Pleistocene terrace deposits were collected by Minch and students from Saddleback College in January of 1977 , at which time the original collections and locality designations were made. Ashby and Minch made additional collections of these localities in August of 1983. In December of 1983, Ashby conducted a final examination of these localities and took additional coral samples for radiometric dating.

\section{Locality distribution and methods}

A diverse and abundant fossil invertebrate assemblage was collected from nine localities along a very prominent twelve-meter marine terrace in the Mulegé area. Three localities in the underlying, upper Pliocene Infierno Formation yielded a sparse molluscan fauna. moniano y que probablemente fueron formadas como resultado de transgresiones y regresiones durante el Pleistoceno tardío. También menciona fósiles abundantes que se encuentran en la terraza de $+12 \mathrm{~m}$ mientras que los fósiles son escasos y poco desarrollados en la terraza de $+9 \mathrm{~m}$.

\section{El presente trabajo}

El trabajo de campo de este reporte se desarrolló entre 1977 y 1983. Los depósitos de las terrazas del Pleistoceno fueron muestreadas por Minch y estudiantes de Saddleback College en enero de 1977, cuando se realizaron las colectas originales y la designación de las localidades. En agosto de 1983, Ashby y Minch llevaron a cabo una serie de colectas adicionales en estas localidades. En diciembre de 1983, Ashby procedi6 a un examen final de estas localidades y tomó muestras adicionales de corales para efectuar un fechado radiométrico.

\section{Distribución de las localidades y métodos}

Se colectó un ensamblaje fósil de invertebrados diversos y abundantes a partir de nueve localidades a lo largo de una terraza marina muy prominente $(+12 \mathrm{~m})$ en el área de Mulegé. Se colectaron algunos moluscos dispersos en tres localidades correspondientes al Plioceno superior, infrayacente y correspondiente a la Formación Infierno.

Ocho de las nueve localidades del Pleistoceno-SDSNH 3249, 3250, 3258, 3259, $3260,3261,3262$ y 3263 - fueron de las terrazas del Pleistoceno en la vecindad inmediata del estuario de Mulegé. La lacalidad 3256 pertenece a Punta Gallito, $6 \mathrm{~km}$ al sur de Mulegé (Fig. 2). Las tres localidades en rocas del Plioceno fueron muestreadas bajo los depósitos de terrazas del Pleistoceno. La localidad 3255 está junto a la 3256 en Punta Gallitu, la 3251 está bajo la 3250 a lo largo de la aeropista de La Serenidad y la 3257 se encuentra bajo la 3261 justo al norte del estuario de Mulegé (Fig. 2).

Cada una de las localidades del Pleistoceno está dada por un área más que por un punto específico (Fig. 2). La mayoría del 
Eight of the nine Pleistocene localities -SDSNH 3249, 3250, 3258, 3259, 3260, 3261, 3262 and 3263- are located in the Pleistocene terrace deposits in the immediate vicinity of the Mulegé estuary. Locality 3256, is located at Punta Gallito, $6 \mathrm{~km}$ south of Mulegé (Fig. 2). The three localities in Pliocene rocks are located below Pleistocene terrace deposits. Locality 3255 is located below 3256 at Punta Gallito, 3251 lies below 3250 along the La Serenidad airstrip, and 3257 is located below 3261 just north of the Mulegé estuary (Fig. 2). material fósil está expuesto como un depósito de deflación en las superficies de erosión de las terrazas o en pequeñas grietas cortadas en estas superficies.

Las muestras de coral para el fechado radiométrico se obtuvieron de las localidades $3250,3258,3260$ y 3263. Los dos únicos especímenesde Porites califomica que proporcionaron cantidades suficientes de aragonita para utilizarse en el fechado fueron colectadas in situ de las localidades 3258 y 3260 .

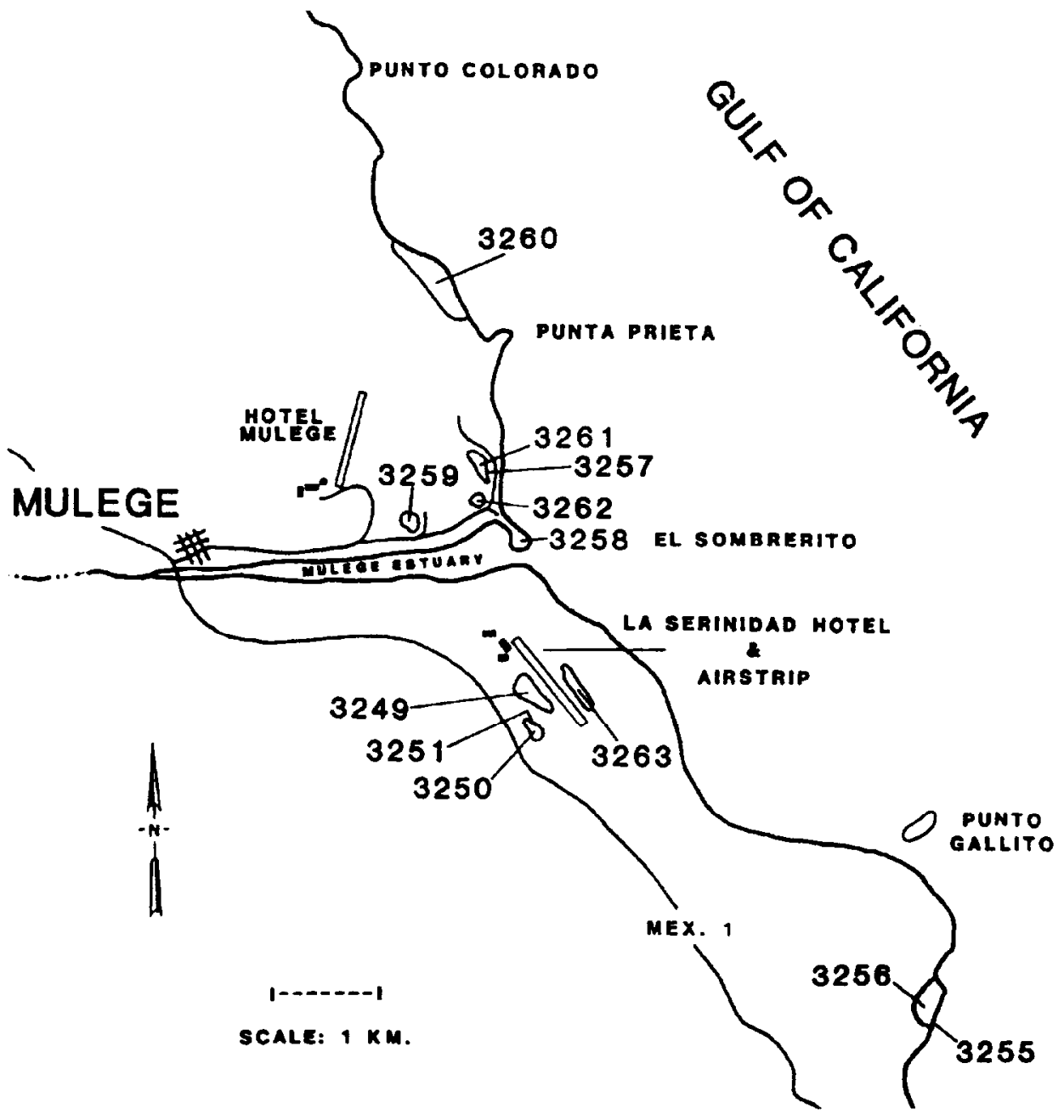

Figure 2. Distribution of fossil localities

Figura 2. Distribución de las localidades de los fósiles. 
Each of the Pleistocene localities is designated by an area rather than a specific point (Fig. 2). Much of the fossil material is exposed as a deflation-lag deposit on the eroded surfaces of these terraces or in small gulleys cut into these surfaces.

Coral samples for radiometric dating were obtained from localities $3250,3258,3260$ and 3263. The only two specimens of Porites californica that yielded sufficient quantities of aragonite to provide a reliable date were collected in situ from localities 3258 and 3260.

\section{STRATIGRAPHY}

The Mulegé area is underlain by volcaniclastic agglomerates, ruffs, and basalts of the upper Oligocene to lower Miocene Comondú Group (McFall, 1968). Locally overlying the Comodu Group along an unconformity are upper Pliocene marine coquinas, marls, and sandstones of the Infierno Formation of Wilson (1948). The Comondú Formation and Infierno Formation are in turn unconformably overlain by upper Pleistocene fossiliferous marine sandstone and gravel terrace deposits of the Mulegé Formation (new name). The terrace is locally covered by alluvium of Holocene dune sands.

\section{Comondú Group (upper Oligocene - lower Miocene)}

The Comondú Formation was named for volcanic sequences near Comondú (Heim, 1922 , p.542). This Formation forms the extensive basement rocks of the Mulegé area. McFall (1968) elevated this formation to group status and subdivided these volcaniclastic rocks into six formations with an aggregate thickness of 13,500 feet. Two small gabbroic intrusive bodies mapped as "Tertiary intrusions" by McFall (1968, plate 1) are exposed in the Mulege area. One is on the north side of the estuary near the Hotel Vista Hermosa and the other forms El Sombrerito, a prominent round island at the mouth of the estuary (Fig. 2, Plate 1). Rocks of the Comondu Group were not examined in this study.

\section{ESTRATIGRAFIA}

El área de Mulegé se encuentra cubierta por aglomerados volcanoclásticos, tobas $y$ basaltos del Oligoceno superior al Mioceno inferior, del Grupo Comondú (McFall, 1968). Sobreyaciendo localmente al Grupo Comondú a lo largo de una inconformidad se encuentran coquinas marinas, margas y areniscas de la Formación Infierno de Wilson (1948). La Formación Comondú y la Formación Infierno se encuentran a su vez cubiertas y en inconformidad por depósitos en terrazas de areniscas marinas y gravas del Pleistoceno superior de la Formación Mulegé (nuevo nombre). La terraza está cubierta por aluvión o por arenas de duna del Holoceno.

\section{Grupo Comondú (Oligoceno superior-Mioceno inferior)}

La Formación Comondú se llamó de acuerdo a las secuencias volcánicas cerca de Comondú (Heim, 1922, p.542). Esta formación forma las extensas rocas de subsuelo de la zona de Mulegé. McFall (1968) le confirió a esta formación la categoría de grupo y subdividió estas rocas volcanoclásticas en seis formaciones de un espesor de 13,500 pies. Dos pequeños cuerpos intrusivos, identificados en un mapa como "intrusiones del Terciario" por McFall (1968, placa 1), están expuestos en el área de Mulegé. Uno está en la parte norte del estuario, cerca del Hotel Vista Hermosay el otro forma El Sombrerito, una isla redonda y prominente en la boca del estuario (Fig. 2, placa 1). No se examinaron rocas del grupo Comondú en el presente estudio.

\section{Formación Infierno (Plioceno superior)}

La Formación Infierno fue nombrada por Wilson (1948, p. 1768) por los afloramientus de arenisca marina fosilifera del Plioccno superior en el Arroyo del Infierno cerca de Santa Rosalia. Wilson y Rocha (1955, p.37) explicaron detalladamente la estratigrafra, la extensión del área y la litología de esta formación tal y como se presenta en el área de Santa Rosalía. La Formación Infierno en el área de Mulegé consiste de arkosas líticas 


\section{Infierno Formation (upper Pliocene)}

The Infierno Formation was named by Wilson (1948, p. 1768) for exposures of upper Pliocene fossiliferous marine sandstones in Arroyo del Infierno near Santa Rosalía. Wilson and Rocha (1955, p. 37) detailed the stratigraphy, areal extent, and lithology of this formation as exposed in the Santa Rosalifa area. The Infierno Formation in the Mulegé area consists of orangish-brown, well-sorted, silty, lithic arkose. Generally they are moderately sorted, poorly indurated and are to poorly bedded.

McFall (1968) mapped and described what he believed to be the Infierno Formation in the Concepcion Bay area. He recorded many fossil molluscs that were collected from several of his localities. He also mentioned some seemingly Pleistocene fossils collected from the same localities that he and $L$. Hertlein (in McFall, 1968) considered "sloughed from the Late Pleistocene terrace deposits onto the Pliocene rocks". As a result of this conclusion, McFall referred to these rocks as of Pliocene age and probably correlative with the Infierno Formation in Santa Rosalía. arcillosas, bien sorteadas, color naranja café. Generalmente son moderadamente sorteadas, poco litificadas y parcialmente estratificada a masiva.

McFall (1968) trazó en un mapa y describió lo que él creyó que sería la Formación Infierno en el área de Bahía Concepción. Registró muchos fósiles de moluscos que se colectaron en varias localidades. También mencionó unos fósiles, aparentemente del Pleistoceno, colectados en los mismos lugares que él y L. Hertlein (en McFall, 1968) consideran que "han pasado de depósitos en terraza del Pleistoceno tardío a las rocas del Plioceno". Como resultado de ello McFall consideró que estas rocas pertenecían al Plioceno y estaban probablemente en correlación con la Formación Infierno en Santa Rosalía.

\section{Edad y correlación}

Fósiles de arenisca amarillenta café debajo de los depósitos en terraza del Pleistoceno superior indican una edad del Plioceno tardio y una correlación con la Formación Infierno del área de Santa Rosalía. Existe

Table I. Fossils collected from the Infierno Formation in the Mulegé area from McFall (1968), with additions made during the present study. Known geologic ranges of these molluscs in the Gulf of California (Durham, 1950) are also included.

Tabla I. Fósiles de la Formación Infierno recolectados en el área de Mulegé por McFall (1968), con adiciones hechas durante el presente estudio. Se incluyen también variaciones geológicas conocidas de estos moluscos en el Golfo de California (Durham, 1950).

\begin{tabular}{|c|c|c|c|c|c|c|c|}
\hline & \multicolumn{7}{|c|}{ R A N G E } \\
\hline & & \multicolumn{2}{|c|}{ Pliocene } & \multicolumn{3}{|c|}{ Pleistocene } & \multirow[t]{2}{*}{ Recent } \\
\hline & & $\mathrm{E}$ & $\mathrm{L}$ & $\mathbf{E}$ & $\mathbf{M}$ & $\mathrm{L}$ & \\
\hline Ostrea heermanni & $\mathrm{X}$ & $\mathbf{X}$ & $\mathrm{X}$ & & & & \\
\hline Ostrea vespertina & & $\mathrm{X}$ & $\mathrm{X}$ & $?$ & & & \\
\hline Chione califomiensis & & & $?$ & $\mathbf{X}$ & $\mathbf{X}$ & $\mathbf{X}$ & $\mathbf{X}$ \\
\hline Argopecten circularis & & & $?$ & $\mathbf{X}$ & $\mathbf{X}$ & $x$ & $\mathrm{X}$ \\
\hline Anomia peruviana & & & $\dot{x}$ & $\mathrm{X}$ & $\mathrm{X}$ & $\mathrm{X}$ & $\mathbf{X}$ \\
\hline Tagelus californianus & & & $\mathrm{X}$ & $\mathrm{X}$ & $\mathbf{X}$ & $\mathrm{X}$ & $\mathrm{X}$ \\
\hline Polinices sp. & $\mathbf{X}$ & $\mathbf{x}$ & $\mathrm{X}$ & $\mathrm{X}$ & $\mathrm{X}$ & $\mathrm{x}$ & $\mathrm{X}$ \\
\hline Hanetia cf. $H$. pallida & & & $\mathrm{X}$ & $\mathrm{X}$ & $\mathrm{X}$ & $\mathrm{X}$ & $\mathrm{x}$ \\
\hline Pecten (Argopecten) abietis & & $\mathbf{X}$ & $\mathrm{X}$ & & & & \\
\hline Pecten (Nodiopecten) subnodosus & & $\mathrm{X}$ & $\mathrm{X}$ & $\mathrm{x}$ & $X$ & $\mathrm{X}$ & $X$ \\
\hline
\end{tabular}




\section{Age and correlation}

Fossils from the orangish-brown sandstones below the upper Pleistocene terrace deposits indicate a late Pliocene age and a correlation with the Infierno Formation of the Santa Rosalía area. The presence of an abundance of Ostrea vespertina with minor Argopecten circularis, Anomia penuiana and Chione califomiensis, as well as the other species cited above.

The presence of Chione califomiensis, Anomia peruviana and Argopecten circularis in the fauna clearly indicate a late Pliocene to recent age, according to work in the Gulf of California by Durham (1950). Ostrea heermanni, Ostrea vespertina, and Pecten abietis are only known from rocks of lower Pliocene to upper Pliocene age. The overlapping ranges of these species establish an upper Pliocene late age for these rocks.

The sediments on Punta Concepción (due East, across Conception Bay from Mulegé) greatly resemble those in the Mulegé area. The same orangish-brown sandstones exist at this locality and contain an invertebrate fauna indicative of Pliocene age (Judy T. Smith, personal communication). These Pliocene sandstones are overlain by upper Pleistocene terrace deposits as in Mulegé and the dominant marine terrace is present at the same elevation as the one studicd in Mulege $(+12$ $m)$. It appears that these two sections on either side of Bahra Concepción are equivalent and correlation with the Infierno Formation of Santa Rosalía can now be made.

\section{MULEGE FORMATION (upper Pleistocene) (New name)}

The upper Pleistocene deposits on the twelve-meter terrace consist of two distinct lithologic units: a sparsely fossiliferous basal conglomerate up to $4 \mathrm{~m}$ thick, and an overlying highly fossiliferous medium to coarse-grained arkosic sandstone, 1 to $3 \mathrm{~m}$ thick. It is here proposed that the terrace deposits that rest on the twelve-meter abrasion platform be named the Mulegé Formation (new name) after the pueblo near which they presencia abundante de Ostrea vespertina con cantidades menores de Agropecten circularis, Anomia peruviana y Chione califomiensis así como otras especies arriba mencionadas.

La presencia de Chione califomiensis, Anomia peruviana y Argopecten circularis en la fauna indica claramente una edad del Plioceno tardío hasta una edad reciente de acuerdo a un trabajo de Durham (1950) en el Golfo de California. Ostrea Heermanni, Ostrea vespertina y Pecten abietis se conocen sólo en rocas del Plioceno inferior al Plioceno superior. Las distribuciones de estas especies establecen una edad del Plioceno tardío superior para estas rocas.

Los sedimentos en Punta Concepción (exactamente al Este, cruzando la Bahía Concepción desde Mulegé) se parecen mucho a los que se encuentran en el área de Mulegé. La misma arenisca café amarillenta existe en este lugar y contiene una fauna invertebrada que indica una edad del Plioceno (Judy T. Smith, comunicación personal). Estas areniscas del Plioceno están cubiertas por depósitos en terraza del Pleistoceno superior como en Mułegé y la terraza marina dominante está a la misma elevación que la estudiada en Mulegé $(+12 \mathrm{~m})$. Parece que estas dos secciones en ambos lados de Bahía Concepción son cquivalentes y se puede hacer una correlación con la Formación Infierno de Santa Rosalía.

FORMACION MULEGE (Pleistoceno Superior) (Nuevo nombre)

Los depósitos del Pleistoceno superior en la terraza de doce metros consisten de dos unidades litológicas distintas: un conglemerado de base escasamente fosilífero de hasta cuatro metros de espesor y arenisca cubriéndolo, altamente fosilifera de grano mediano a grueso, de uno a tres metros de cspesor. Sc propone que los depósitos en terraza que descansan sobre la plataforma de erosión de doce metros se llamen Formación Mulegé (nuevo nombre) según el pueblo que se encuentra cerca. La plataforma de erosión (terraza) cubierta por la Formación Mulegé se llama la Terraza Mulegé (nuevo nombre). 
occur. The abraision platform (terrace) which is mantled by the Mulege Formation is designated as the Mulegé Terrace (new name).

\section{Type section}

Locality 3256 at Punta Gallito is designated as the type section of the Mulege Formation. The Mulege Terrace is best exposed at this locality, and the underlying upper Pliocene Infierno Formation and overlying Holocene dune sand are present to define the lower and upper limits of the terrace gravels. The type section was measured along the beach, on approximately $.3 \mathrm{Km}$ north of the first arroyo south of the point.

\section{Holocene dune sand}

Thicknes (in meters) variable.

\section{Upper Pleistocene Mulegé Formation}

Sandstone. Gray, loose, poorly bedded to massive, moderately sorted, lithic arkoses. Some channeling and cross-bedding present. Fossils evenly distributed throughout.

\section{$2.3 \mathrm{~m}$}

Conglomerate. Reddish-brown, deeply weathered, clast supported, lenticular, pebble- to cobble conglomerates. Two distinct beds are recognized. The upper bed is $2.1 \mathrm{~m}$ thick and slightly coarser, the lower bed is $2.4 \mathrm{~m}$. Fossils are sparsely distributed throughout both units.

\section{$4.5 \mathrm{~m}$}

Terrace unconformity

\section{Upper Pliocene Infierno Formation}

Orangish-brown, moderately indurated, massive, moderately sorted, silty, sub-arkosic sandstone.

\section{$4.3 \mathrm{~m}$}

Sea level, base not visible.

Total $11.1 \mathrm{~m}$

\section{Sección tipo}

La localidad 3256 en Punta Gallito es la sección típica de la Formación Mulegé. La Terraza Mulegé está mejor expuesta en esta localidad y la Formación Infierno de base del Plioceno superior y la arena de dunas del Holoceno que se encuentran encima sirven para definir los límites inferiores y superiores del graven de la terraza. Se midió la sección tipo a lo largo de la playa, aproximadamente a $0.3 \mathrm{~km}$ al norte del primer arroyo al sur del punto.

\section{Dunas de arena del Holoceno}

variable

\section{Formación Mulegé Pleistoceno superior}

Arenisca. Gris, suelta, parcialmente estratificada a masiva, moderadamente sorteada, arkosas líticas. Se presentan algunas estructuras de canal y algo de estratificación cruzada. Los fósiles se encuentran distribuidos a lo largo del estrato.

\section{$2.3 \mathrm{~m}$}

Conglomerado. Rojizo a café, retrabajado, con soporte de clastos, lenticular, conglomerados de pebble a cobble. Se reconocieron dos estratos diferentes. El superior es de 2.1 metros de espesory ligeramente más grueso, el estrato inferior es de 2.4 metros de espesor Los fósiles se encuentran esparcidos y distribuidos en ambas unidades.

$4.5 \mathrm{~m}$

Discontinuidad de la terraza

\section{Formación Infierno Plioceno Superior}

Arenisca sub-arkosa café naranja, moderadamente litificada, masiva, moderadamente sorteada, ligeramente arcillosa.

\section{$4.3 \mathrm{~m}$}

Nivel del mar, la base no es visible.

Total $11.1 \mathrm{~m}$ 
More readily accessible typical sections are exposed along the La Serenidad airstrip at localities 3249 and 3263 (Fig. 2).

\section{Paleogeography}

The twelve-meter terrace is exposed almost continuously from Punta Colorado 1 $\mathrm{Km}$ north of Mulege to Punto Gallito $5 \mathrm{~km}$ to the South and is also found on Punta Concepción across Concepción Bay from Mulegé. In the Mulegé area the terrace forms a $1.5 \mathrm{~km}$-wide gently sloping surface which abuts against the volcanics of the Comondu Group. These volcanics formed a steep sea cliff during the late Pleistocene and possibly during the late Pliocene. Over much of its extent, this terrace is locally dissected by streams or covered by alluvium or recent dune sands. The large areal extent of this terrace and the presence of a well-developed segment of the twelve-meter terrace on El Sombrerito, which is composed of resistant gabbro suggests that sea level remained at this elevation for a relatively long period of time.

\section{Lithology}

The Pleistocene deposits consist of material derived from the underlying Comondú Group mixed with reworked sandstones and rip-up clasts from the Infierno Formation. The basal conglomeratic unit consists of well-rounded, reddish-brown pebbles to cobbles of metavolcanic composition. The underlying conglomerates also contain leached and highly weathered fossils.

The sandstone unit consists of gray to yellowish-brown, poorly indurated, massive to poorly-bedded, moderately to poorly sorted, subrounded to rounded, medium-grained lithic arkoses. This unit is 1 to $3 \mathrm{~m}$ in thickness, averaging $2 \mathrm{~m}$. The majority of the fossil material was collected from the overlying sandstones.

\section{Relationship to other units}

The basal conglomerates, or terrace sands where conglomerates are absent, rest in slight angular unconformity upon the silty sandstones of the Infierno Formation. This
Secciones típicas de acceso más fácil, se encuentran expuestas a lo largo de la pista de aterrizaje La Serenidad en las localidades 3249 y 3263 (Fig. 2).

\section{Paleogeografía}

La terraza de doce metros está expuesta de manera casi contínua desde Punta Colorado $1 \mathrm{~km}$ al norte de Mulegé hasta Punta Gallito $5 \mathrm{~km}$ al sur y se encuentra también en Punta Concepción del otro lado de la Bahía Concepción a partir de Mulegé. En el área de Mulegé, la terraza forma una superficie de pendiente suave de $1.5 \mathrm{~km}$ de ancho y termina en la zona volcánica del Grupo Comondú. Esta zona volcánica formó un peñasco marino abrupto durante el Pleistoceno tardío y posiblemente durante el Plioceno tardío. Esta terraza se encuentra dividida localmente, en su mayor parte, por arroyos o cubierta por aluvión o dunas de arena recientes. La gran extensión de esta terraza y la presencia de un segmento bien desarrollado de la terraza de doce metros en El Sombrerito, el cual se compone de gabro resistente, sugiere que el nivel del mar permaneció en esta elevación durante un período de tiempo relativamente largo.

\section{Litología}

Los depósitos de Pleistoceno se componen de un material derivado del Grupo Comundú subyacente mezclado con arenisca retrabajada y clastos en rip up de la Formación Infierno. La unidad conglomerada de base se compone de pebbles a cobbles redondeados, color café rojizo, de composición metavolcánica. Los conglomerados subyacentes también contienen fósiles substituidos y altamente trabajados.

La unidad de areniscas se compone de arkosas líticas de grano mediano, sub-redondeados a redondeados, moderadamente a poco sorteadas, masiva a parcialmente estratificada, poco litificada, de color café naranja. Esta unidad tiene de uno a tres metros de espesor, con un promedio de dos metros. La mayor parte del material fósil se colectó en las areniscas subyacentes. 
relationship can be best observed at locality SDSNH 3251. In this cut for the old road, upper Pliocene silty sandstones of the Infierno Formation dip of about three degrees to the East. The flat-lying, upper Pleistocene terrace sandstones rest on the truncated edge of these beds. This relationship appears to be depositional in nature and not due to tectonic activity.

\section{Age of terrace deposits}

The Pleistocene deposits have been assigned a Pleistocene age by Gabb (1867), Beal (1948), McFall (1968), and Ortleib (1978). The present study of the fauna obtained from these terrace deposits has yielded diagnostic species which indicate a late Pleistocene age. Cancellaria cassidiformis and Strombus granulatus are found only in sediments of upper Pleistocene to Holocene age. Gyrineum strongi and Cancellaria coronadoensis are only found in rocks of Pleistocene age and are presently extinct in the Gulf of California (Durham, 1950). The overlapping ranges of these diagnostic species indicate a late Pleistocene age for this fauna.

This age determination is corroborated by a Uranium-Thorium decay-series (U234/Th 230) date on two specimens of Porites califomica (Ashby, $\mathrm{Ku}$ and Minch, in press). The ages obtained using this method are $124,000 \pm 6000$ years and $144,000 \pm 7000$ years. These dates correspond to the well-established $5 \mathrm{e}$ Sangamon interglacial high sea-stand of Shakleton and Opdyke (1973).

\section{Tectonic activity}

No evidence of faulting was observed to have affected either the upper Pliocene sediments or the upper Pleistocene terraces at any of the localities. The linear Mulegé estuary may be fault controlled. The lack of offset between equivalent $+12 \mathrm{~m}$ terraces on either side of the Mulegé estuary indicates there has been no vertical Quaternary movement on any postulated fault. The "dike controlled" hypothesis of McFall $(1968$, p. 16) appears to be the best explanation of the position of the estuary

\section{Relación con otras unidades}

Los conglomerados de base, o terrazas de arena en donde no hay conglomerados, descansan en inconformidad ligeramente angular sobre las areniscas arcillosas de la Formaci on Infierno. Esta relación se puede observar mejor en la localidad SDSNH 3251. En este corte, hacia la vieja carretera, areniscas arcillosas del Plioceno superior de la Formación Infierno se inclinan unos tres grados hacia el Este. Las areniscas en terraza plana del Pleistoceno superior descansan sobre los bordes truncados de estas estratificaciones Parece que esta relación es de naturaleza depositacional y que no se debe a una actividad tectónica.

\section{Edad de los depósitos de terraza}

Gabb (1867), Beal (1948), McFall (1968) y Ortleib (1978) asignaron la edad del Pleistoceno a los depósitos. En el presente estudio mediante la fauna encontrada en los depósitos en terraza se ha podido asignar a las especies una edad de Pleistoceno tardío. Cancelaria cassidiformis y Strombus granulatus se encuentran solamente en sedimentos de la edad del Pleistoceno superior al Holoceno. Gyrineum strongi y Cancellaria coronadoensis se encuentran solamente en rocas de la edad del Pleistoceno y actualmente están extintos en el Golfo de California (Durham, 1950). Los rangos sobrepuestos de estas especies indican una edad del Pleistoceno tardío.

La determinación de edad se corrobora mediante una datación radiométrica por series de decadencia (U 234/Th 230) de dos especímenes de Ponites califomica (Ashby, $\mathrm{Ku}$ y Minch, en imprenta). Las edades obtenidas mediante este método son $124,000 \pm 6000$ años y $144,000 \pm 7000$ años. Estas fechas corresponden al alto marino interglacial del $5 e$ Sangamaniano de Shakleton y Opdyke (1973).

\section{Actividad tectónica}

Aparentemente ninguna falla ha afectado los sedimentos del Plioceno superior ni las trazas del Pleistoceno superior en ninguna de estas localidades.El estuario lineal Mulegé puede ser controlado por falla. La ausencia de 
There has been a lack of major uplift along this section of the coastline since late Pliocene time. The near shore upper Pliocene and upper Pleistocene sediments exist at elevation close to the present shoreline. This is contrary to the conclusions reached by McFall (1968, p. 20). Older faults clearly cut the Miocene volcanics, but evidence of Coastal uplift or downwarping since the late Pliocene does not exist in the Mulegé area.

The $+12 \mathrm{~m}$ height of the marine terrace itself does not demonstrate substantial post-late Pliocene uplift in this area of the Gulf of California. The height of sea level during this part of the Sangamon interglacial was almost high enough to account for the elevation of this terrace. Numerous authors have suggested worldwide eustatic rises in sea level during the Sangamon interglacial $5 e$ high sea-stand. $A+6 \pm 2 m$ is a well established paleo sea level elevation during the $5 \mathrm{e}$ high sea-stand (Mathews, 1973). Other authors have suggested $+6 \mathrm{~m}$ rises during the $5 \mathrm{e}$ Sangamon interglacial high sea-stand (Bender, et al., 1979; Stearns, 1976). It is our conclusion that the Mulegé area has experienced as little as 4 to $6 \mathrm{~m}$ of isostatic uplift since the late Pleistocene.

\section{Alluvium and slopewash (upper Pleistocene - Holocene)}

Following the regression of marine waters at the close of the Sangamon interglacial period, surficial water activity and subsequent erosion of the Comondú highland have produced a mantle of alluvial gravels of varying thickness over much of the late Pleistocene terrace. Only in areas that were isolated from erosion or deposition of alluvial cover are the terrace deposits exposed. Recent dune sand is particularly evident at Punta Gallito, where it covers the Pleistocene terraces. The genesis of these aeolian dunes is explained by McFall (1968, p. 12) as follows:

"Patches of dunes have formed and are still active south of the mouths of large arroyos where the coastal configuration permits the prevailing north winds to move the sediment-laden water southward, stack the desplazamiento entre las terrazas de $+12 \mathrm{~m}$ equivalentes en ambos lados del estuario Mulegé indica que no ha habido ningün movimiento vertical del Cuaternario en ninguna falla propuesta. La hipótesis "de control de diques" de McFall (1968, p.16) parece ser la mejor explicación de la posición del estuario.

No ha habido ningún levantamiento importante de esta sección de la costa desde el Plioceno tardío. Los sedimentos del Plioceno superior y del Pleistoceno superior cercanos a la orilla se encuentran sobre elevaciones cerca de la linea costera actual. Esto contradice las conclusiones de McFall (1968, p.20). Algunas fallas más antiguas cortan claramente la zona volcánica del Mioceno, pero no hay muestras de elevación o hundimiento desde el Plioceno tardío en el área de Mulegé.

La altura de $+12 \mathrm{~m}$ de la terraza marina en sf no da indicaciones de alguna elevación importante del Plioceno post-tardio en esta región del Golfo de California. El nivel del mar durante esta parte del interglacial Sangamoniano fue casi lo suficientemente elevada como para justificar la elevación de esta terraza. Numerosos autores han sugerido levantamientos eustáticos mundiales en el nivel del mar durante el interglacial Sangamoniano. Un +6 $\pm 2 \mathrm{~m}$ es una paleoelevación del nivel del mar bien establecida durante el 5e Sangamoniano (Mathews, 1973). Otros autores han sugerido levantamientos de $+6 \mathrm{~m}$ durante la transgresión interglacial 5e Sangamoniano (Bender, et al., 1979; Stearns, 1976). Nuestra conclusión es que el área de Mulegé sufrió un levantamiento isostático de sólo 4 a $6 \mathrm{~m}$ desde el Pleistoceno tardío.

\section{Aluvión y Depósitos de Bajada (Pleistoceno} superior - Holoceno)

Siguiendo la regresión de las aguas marinas al finalizar el período interglacial Sangamoniano, una actividad del agua superficial y erosión consecuente de las tierras altas de Comondú han producido un manto de grava aluvial de distinto espesor sobre la mayor parte de la terraza del Pleistoceno tardío. Los depósitos en terraza están expuestos sólo en las áreas protegidas de la erosión o de la depositación de una cobertura aluvial. En 
sediment along the beach, winnow out the fines, and drive the sand inland as dunes. This has occured at Punta Gallito, just south of Mulegé."

\section{PALEOENVIRONMENTS}

The paleonvironmental record of the Mulegé area is not well defined because of the limited preservation of sediments in this area. Only the upper Pliocene and upper Pleistocene sediments are recognized in the Mulegé area. The rest of the Tertiary and Ouaternary record has either been destroyed by erosion, covered by sediments or was not deposited in this area. A faunal list of fossils obtained from the nine upper Pleistocene localities was compiled and the relative abundance is given for each species present at each locality (Table II).

The Mulegé estuary was in existence in the late Pliocene and in the late Pleistocene. The estuary may have existed during the early and middle Pleistocene; however, fossil evidence does not exist to verify its existence. Any sediments deposited during this time either have been destroyed or are as yet unrecognized.

\section{Late Pliocene}

Fossils at localities SDSNH 3251, 3257 and below 3263 (no locality number) contain Ostrea vespertina and Anomia penuviana as an in situ death assemblage. Oysters typically occur in shallow, brackish waters attached to mangrove roots or as patch reefs on rocks along the shores of estuaries or shallow embayments. Anomia peruviana presently occurs in shallow, slightly brackish waters in quiet areas that are sheltered from wave energy (Keen, 1971). This type of assemblage would likely be found just inside the mouth of an estuary. At locality 3251 and below 3263 the added presence of Argopecten circularis suggests slightly more normal salinities. This area was more exposed to open marine waters but still dominantly influenced by an estuarine environment. All three of the aforementioned taxa have calcitic shells and are com-
Punta Gallito son características las dunas de arena recientes, cubriendo las terrazas del Pleistoceno. McFall (1968, p.12) explica la génesis de estas dunas eólicas de la manera siguiente:

"Las dunas se han formado y todavía son activas en el sur de las bocas de los grandes arroyos donde la configuración costera permite que el viento dominante del Norte desplace el agua cargada de sedimento que se acumula a lo largo de la playa, por deflación separa la morrena y transporta la arena tierra adentro para formar las dunas. Esto ocurrió en Punta Gallito, justo al sur de Mulegé".

\section{PALEOAMBIENTES}

El registro paleoambiental del área de Mulegé no está bien definido debido a la preservación limitada de los sedimentos en esta área. Sólo se reconocen los sedimentos del Plioceno superior en el área de Mulegé. El resto del registro del Terciario y Cuaternario ha sido destruido por la erosión, o cubierto por sedimentos o bien no fue depositado en esta área. Se elaboró una lista faunal de los fósiles obtenidos de las nueve localidades del Pleistoceno superior que proporciona la abundancia relativa de cada especie presente en esta localidad (Tabla II).

El estuario Mulegé existía en el Plioceno tardío y en el Pleistoceno tardío. El estuario puede haber existido durante el Pistoceno temprano y mediano; sin embargo no existen fósiles para corroborar su existencia. Cualquier sedimento depositado durante este tiempo ha sido destruido o no se ha podido reconocer todavía.

\section{Plioceno tardío}

Los fósiles en las localidades SDSNH 3251, 3257 y abajo de 3263 ( $\sin$ número de localidad) se han identificado como Ostrea vespertina y Anomia peruviana como una tanatocenocis autóctona. Los ostiones se presentan típicamente en aguas salinas poco profundas, pegados a raices de manglares o como masas arrecifales sobre rocas a lo largo de las orillas de los estuarios o de ensenadas poco profundas. La Anomia peruviana se 
Table II: Faunal lists of material collected from the upper Pleistocene Mulegé Formation.

Tabla II. Lista faunal de material colectado del Pleistoceno tardío en la Formación Mulegé.

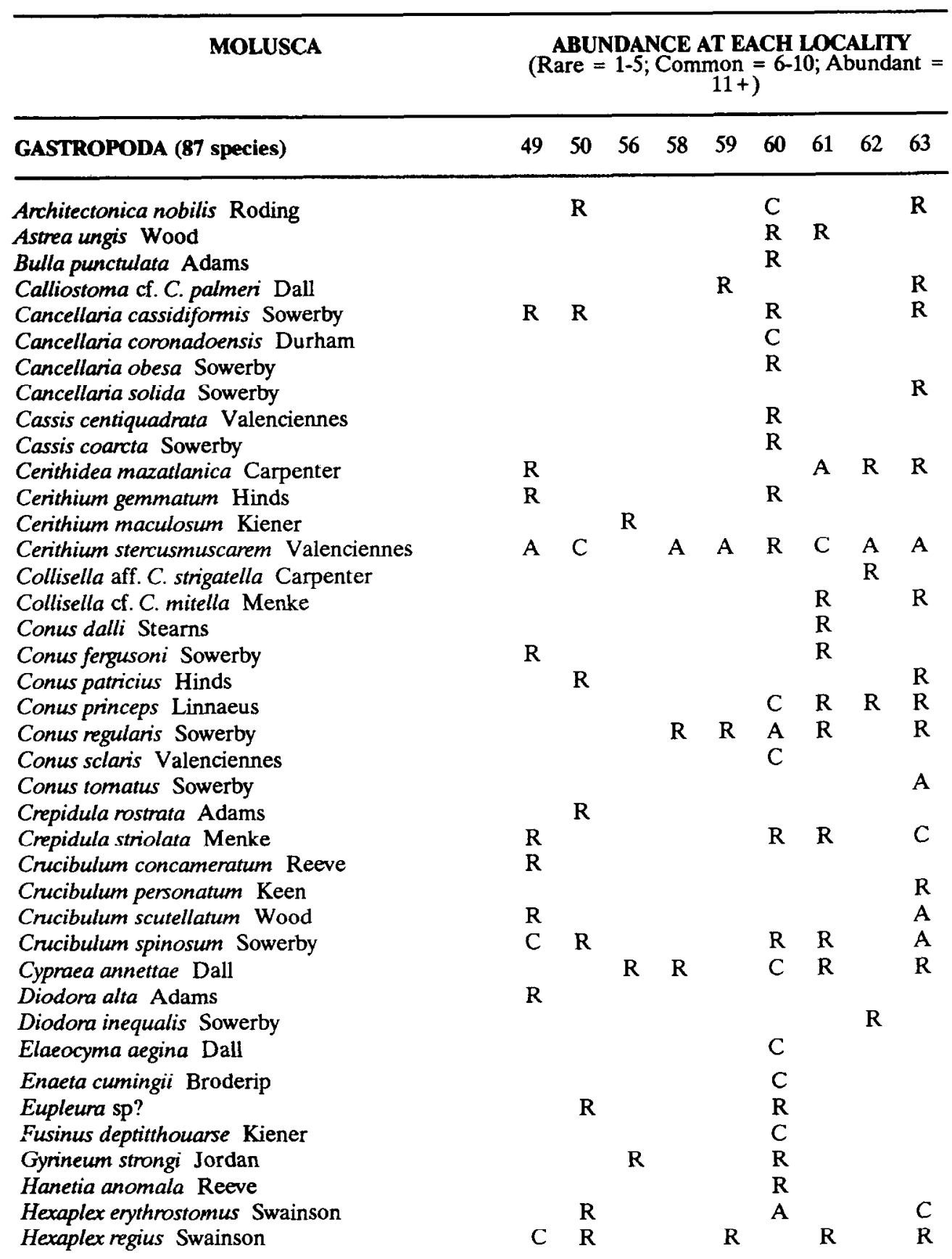


GASTROPODA (87 species) continuación

$\begin{array}{lllllllll}49 & 50 & 56 & 58 & 59 & 60 & 61 & 62 & 63\end{array}$

Hexaplex erythrostomus Swainson

Hexaplex regius Swainson

Hipponix philosus Deshayes

Knefastia cf. $K$. olivacea Sowerby

Knefastia dalli Bartsch

Liocerithium judithae Keen

Lyria cummingii Broderip

Malea ringins Swainson

Melongena patula Broderip and Sowerby

Mitna tristis Broderip

Murex elenensis Dall

Nassarius angulicostis Pilsbry and Lowe

Nassarius tegula Reeve

Neorapana tuberculata Sowerby

Nerita scabricosta Lamarck

Oliva incrassata Lightfoot

Oliva spicata Bolten

Olivella alba Marrat

Olivella dama Wood

Polinices recluzianus Deshayes

Polinices uber Valenciennes

Rhinocoryne humbolti Valenciennes

Serpulorbis sp?

Sinum grayi Deshayes

Solenosteira anomala Reeve

Solenosteira mendozana Berry

Strombina paceana Hinds

Strombus galeatus Swainson

Strombus gracilior Sowerby

Strombus granulatus Swainson

Strombus peruvianus Swainson

Tegula rugosa Adams

Tegula sp?

Terebra brandi Bratcher and Burch

Terebra cf. T. shyana Bratcher and Burch

Terebra sp?

Terebra variegata Gray

Thais biseralis Blainville

Thais kiosquiformis Duclos

Theodoxus luteofaciatus Miller

Tivela bryoensis Gray

Trimusculus reticulatus Sowerby

Trivia myrae Campbell

Turbo fluctuosus Wood

Turritella gonostoma Kiener

Turritella nodulosa King and Broderip

Tumitella pasada Pilsbry and Olson

Vasum caestus Broderip

$\begin{array}{lllllllll} & \mathbf{R} & & & & \mathbf{A} & & & \mathbf{C} \\ \mathbf{C} & \mathbf{R} & & & \mathbf{R} & & \mathbf{R} & & \mathbf{R} \\ \mathbf{R} & \mathbf{R} & \mathbf{R} & \mathbf{A} & & \mathbf{A} & & & \\ & \mathbf{R} & & & & & & & \\ & & & & & \mathbf{R} & & & \\ & \mathbf{R} & & & & & & & \mathbf{R} \\ & & & & & & & & \mathbf{C} \\ & & & & & \mathbf{R} & & & \\ \mathbf{R} & & \mathbf{R} & & & & & & \mathbf{R} \\ & & & & & \mathbf{C} & \mathbf{R} & & \mathbf{R} \\ & & & & & \mathbf{A} & & & \\ & & & & \mathbf{R} & \mathbf{C} & & \mathbf{R} & \mathbf{C} \\ \mathbf{R} & \mathbf{R} & & \mathbf{C} & \mathbf{R} & \mathbf{C} & & \mathbf{R} & \mathbf{A} \\ \mathbf{R} & \mathbf{R} & \mathbf{R} & \mathbf{R} & \mathbf{C} & \mathbf{R} & \mathbf{R} & \mathbf{R} & \mathbf{R} \\ & \mathbf{R} & & \mathbf{C} & \mathbf{R} & \mathbf{R} & & \mathbf{R} & \mathbf{C} \\ \mathbf{A} & \mathbf{A} & & & & & \mathbf{R} & & \mathbf{A} \\ & \mathbf{R} & \mathbf{R} & \mathbf{R} & \mathbf{R} & \mathbf{R} & & & \mathbf{C} \\ & & & & & & & \mathbf{R} & \end{array}$

\begin{tabular}{|c|c|c|c|c|c|c|}
\hline A & & & & A & $\mathbf{R}$ & \\
\hline A & A & $\mathbf{R}$ & C & $\mathbf{A}$ & $\mathbf{R}$ & C \\
\hline & C & $\mathbf{R}$ & C & A & & \\
\hline $\mathbf{R}$ & $\mathrm{R}$ & & C & $\mathbf{R}$ & & \\
\hline
\end{tabular}

$\begin{array}{lllllllll}\mathbf{A} & \mathbf{R} & \mathbf{R} & \mathbf{R} & \mathrm{C} & \mathrm{A} & & \mathbf{A} & \mathrm{A}\end{array}$

$\begin{array}{lll}\text { A } & & \text { R } \\ \text { R } & & \\ \text { A } & \text { R } & \text { A } \\ \text { A } & & \text { R }\end{array}$

$\begin{array}{lllllllll}\text { A } & \text { A } & \text { A } & \text { R } & \text { R } & \text { A } & R & & \text { A }\end{array}$

A

$\begin{array}{llll}R & R & R & R\end{array}$

$\begin{array}{lllllll} & & & & & & \\ & & & & & \\ & & & & & \\ & & & & & & \\ \text { A } & \text { A } & & \text { A } & \text { R } & \text { R } & \text { A } \\ \text { R } & & \text { R } & & \text { R } & & \text { R } \\ & & & & & & \text { R } \\ \text { C } & & & & & & \text { R }\end{array}$

$\begin{array}{llll}\mathbf{A} & \mathbf{A} & \mathbf{R} & \mathbf{R}\end{array}$

$\begin{array}{lllllllll}\mathbf{A} & \mathbf{R} & \mathbf{A} & \mathbf{A} & \mathbf{R} & \mathbf{A} & \mathbf{A} & \mathbf{R} & \mathbf{A}\end{array}$

$\begin{array}{llllll}\mathbf{R} & \mathbf{C} & \mathbf{A} & \mathbf{R} & \mathbf{R} & \mathbf{R}\end{array}$

$\begin{array}{ll}\mathbf{R} & \mathrm{R} \\ \mathrm{R} & \end{array}$

R $\quad$ R 
Americardia biangulata Broderip \& Sowerby

Amiantis callosa Conrad

Anadara cf. A. reinharti Lowe

Anadara multicostata Sowerby

Anomia peruviana Orbigny

Apolymetis biangulata Carpenter

Anca pacifica Sowerby

Arcopsis solida Sowerby

Argopecten circularis Sowerby

Barbatia gradata Broderip and Sowerby

Barbatia reeveana Orbigny

Brachidontes adamsianus Dunker

Cardita affinis Sowerby

Chama frondosa Broderip

Chama mexicana Carpenter

Chama sordida Broderip

Chama sp?

Chione califomiensis Broderip

Chione fluctifraga Sowerby

Chione gnidia Broderip and Sowerby

Chione kellettii Hinds

Chione tumens Verrill

Codakia distinguenta Tyron

Crassitellites digueti Lamy

Cyclinella aff. C. singleyi Dall

Divalinga perparvula Dall

Divaricella lucasana Dall and Oschner

Donax gouldi Dall

Donax navicula Hanley

Dosinia ponderosa Gray

Felaniella sericata Reeve

Glans affinis Sowerby

Glycymeris gigantea Reeve

Glycymeris multicostata Sowerby

Lyropecten subnodosus Sowerby

Macoma nasuta Conrad

Mactra sp?

Megapitaria squalida Sowerby

Modiolus capax Conrad

Ostrea angelica Rochebrune

Ostrea megadon Hanley

Ostrea palmula Carpenter

Panopea globosa Dall

Papyridea aspera Sowerby

Pecten vogdesi Arnold

Periglypta multicostata Sowerby

Pinna cf. P. rugosa Sowerby

Pitar sp?
$\mathbf{R}$

$\begin{array}{lllllllll} & & & & & & & & \mathbf{R} \\ \mathbf{R} & \mathbf{R} & \mathbf{R} & \mathbf{R} & & \mathbf{A} & \mathbf{R} & \mathbf{R} & \mathbf{R} \\ \mathbf{R} & & & & \mathbf{R} & & \mathbf{R} & \mathbf{R} & \mathbf{R} \\ & & & & \mathbf{R} & & & & \\ & & & & & & \mathbf{R} & & \mathbf{R} \\ \mathbf{R} & \mathbf{R} & \mathbf{R} & & \mathbf{R} & & & & \mathbf{R} \\ \mathbf{R} & \mathbf{R} & \mathbf{R} & \mathbf{R} & \mathbf{R} & \mathbf{R} & & & \\ & & \mathbf{R} & & & & & & \\ & \mathbf{R} & \mathbf{R} & & & & & & \mathbf{R} \\ \mathbf{R} & \mathbf{R} & & \mathbf{R} & & & & \mathbf{R} & \mathbf{R} \\ & \mathbf{R} & & & & & & & \\ \mathbf{R} & & & & & \mathbf{R} & & & \mathbf{R} \\ & & & & & & \mathbf{R} & & \end{array}$

$\begin{array}{llllllll}\text { A } & \text { A } & \text { C } & \text { A } & \text { A } & \text { A } & \text { A } & \text { A }\end{array}$

A A

A

C $\mathrm{R}$ A

A A

R

C

A

R $\quad \mathrm{C} \quad \mathrm{A}$

C $\quad \mathrm{R} \quad \mathrm{A}$

R

$\mathrm{R}$

$\mathrm{R}$

$\begin{array}{lll} & \mathbf{R} & \mathbf{R} \\ \mathrm{R} & \mathrm{A} & \mathrm{R} \\ & & \text { A }\end{array}$

A $\quad \mathrm{R}$

R $\quad$ R

A $\mathbf{R}$

$\begin{array}{llll}A & R & R & A\end{array}$

R $\quad \mathrm{R}$

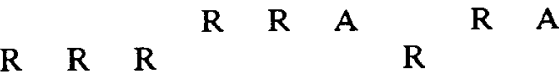

$\begin{array}{lllllll} & \mathbf{R} & \mathbf{R} & \mathrm{R} & \mathrm{R} & & \mathrm{R} \\ \mathbf{R} & & \mathrm{A} & & & \mathrm{R} & \mathrm{A}\end{array}$

$\begin{array}{llll}\mathbf{R} & \mathbf{A} & \mathbf{R} & \mathbf{A}\end{array}$

A $\quad$ R

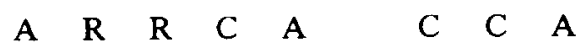

$\mathrm{R}$

R

$\mathbf{R}$

R $\quad \mathrm{R}$

$\mathbf{R}$

$\mathrm{R}$

$\mathrm{R}$

C 
Prototheca grata Say

Prototheca sp?

Semele dicisa Conrad

Semele flavescens Gould

Semele pacifica Dall

Spondylus calcifer Carpenter

Spondylus princeps Broderip

Tagelus califomianus Conrad

Tellina simulans Adams

Tellina cumingii Hanley

Tivela bryoensis Gray

Trachycardium consors Sowerby

Trachycardium panamense Sowerby

Trigoniocardia biangulata Broderip \& Sowerby
$\mathbf{R}$

$\begin{array}{llll}\mathbf{R} & \mathbf{R} & \mathbf{R} & \mathbf{A}\end{array}$

$R$

$\begin{array}{llll}\mathbf{R} & \mathbf{R} & \mathbf{R} \\ & & \mathbf{R}\end{array}$

$\mathbf{R}$

$\mathbf{R}$

$\mathbf{R}$

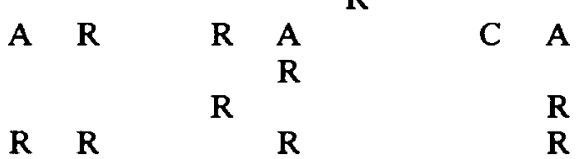

$\begin{array}{lllllllll}R & R & R & R & R & A\end{array}$

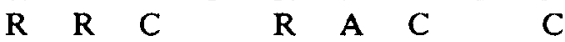

ECHINODERMATA (3 species)

$\begin{array}{lllllllll}49 & 50 & 56 & 58 & 59 & 60 & 61 & 62 & 63\end{array}$

Enallaster? sp. indet.

Encope grandis Agassis

Encope califomica Verrill

Sea Urchin spines

A

Sea Urchin fragments

$\mathbf{R}$

SCAPHAPODA (2 species)

$\begin{array}{lllllllll}49 & 50 & 56 & 58 & 59 & 60 & 61 & 62 & 63\end{array}$

Dentalium pretiosum beryi Smith \& Gordon

A $R \quad R$

ANTHOZOA (1 species)

$\begin{array}{lllllllll}49 & 50 & 56 & 58 & 59 & 60 & 61 & 62 & 63\end{array}$

Ponities califomica Verrill

R $\quad \mathrm{R} \quad \mathrm{R}$

R

(C)

C

ARTHROPODA (1 species)

$\begin{array}{lllllllll}49 & 50 & 56 & 58 & 59 & 60 & 61 & 62 & 63\end{array}$

Balanus sp?

Crab claws

R R

(C)-Denotes dated coral specimen 
Ashby James R., Minch A.J. - Stratigraphy and Paleoecology

CHORDATA (1 species)

$\begin{array}{lllllllll}49 & 50 & 56 & 58 & 59 & 60 & 61 & 62 & 63\end{array}$

Bone fragment

$\mathbf{R}$

Whale bone

$\mathrm{R}$

TRACE FOSSILS

$\begin{array}{llllllll}49 & 50 & 56 & 58 & 59 & 60 & 61 & 62\end{array}$

63

monly found as a differentially preserved assemblage following dissolution of the more common aragonitic taxa (Thomas Demere, personal communication, 1986).

Environment distribution indicated that the Mulege estuary was in existence by late Pliocene time but was much larger during the late Pliocene and late Pleistocene than it is at present. The area encompassing locality 3257 was slightly inside the northern end of the mouth of the estuary and locality 3251 lays at the southern end of the mouth of the estuary, slightly more exposed to the open marine environment (Fig. 3).

The fauna at locality 3255 , five kilometers South at Punta Gallito, indicated a muddy, sand-flat embayment bordered by rocks. Fossils found at this locality include Polinices sp., Chione califomiensis and Tagelus califomianus. The genus Polinices is generally an intertidal sand dweller. Tagelus californianus and Chione califomiensis are present on shallow muddy to sandy bottoms. The fossils at this locality do not occur in situ; however, they are commonly doubly-valved, indicating relatively little post-mortem transport. This area during the late Pliocene was also probably an estuary like Mulegé. encuentra actualmente en aguas ligeramente salinas, poco profundas, tranquilas, protegidas de la energía del oleage (Keen, 1971). Es lo más probable encontrar este tipo de ensamblaje justo dentro de la boca de un estuario. En la localidad 3251 y abajo de la 3263 , la presencia adicional de Argopecten circularis sugiere salinidades ligeramente más normales. Esta área fue más expuesta a aguas del mar abierto aunque permaneció bajo influencia dominante del ambiente estuarino. Los tres grupos taxonómicos arriba mencionados poseen concha calcítica y se encuentran comunmente como un ensamblaje preservado de manera diferencial después de la disolución de los grupos taxonómicos aragoníticos más comunes (Thomas Demere, comunicación personal, 1986).

La distribución ambiental indica que el estuario Mulegé ya exist ía durante el Plioceno tardío pero era mucho más grande durante el Plioceno tardío y el Plestoceno tardio que ahora. El área que abarca la localidad 3257 se encontraba ligeramente adentro, al Norte, de la boca del estuario, mientras que la localidad 3251 está en el extremo sur de la boca del estuario, ligeramente más expuesta al ambiente del mar abierto (Fig. 3).

La fauna en la localidad 3255 , cinco kilómetros al sur de la Punta Gallito, indica una ensenada arenosa, plana y lodosa, rodeada de 


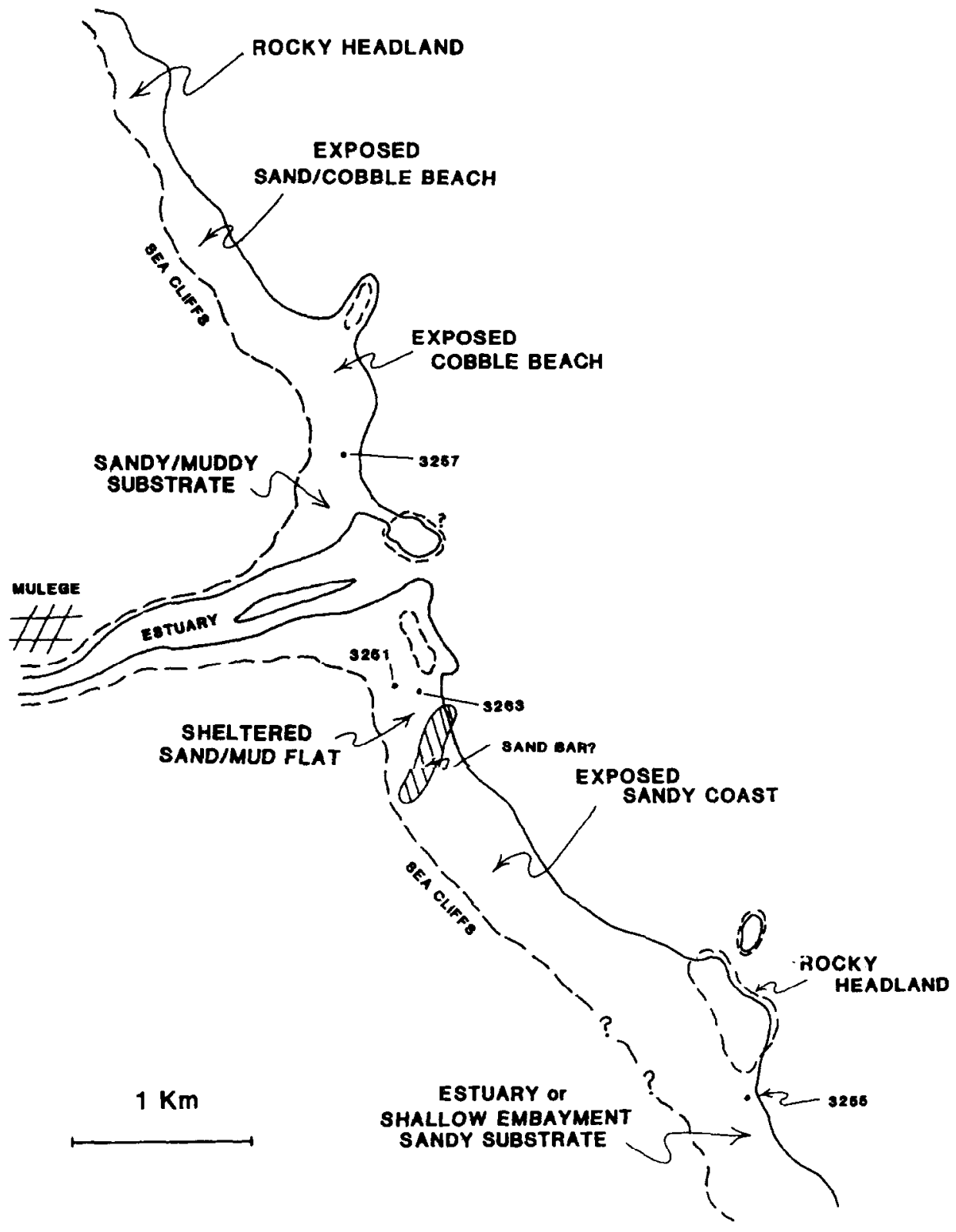

Figure 3. Late Pliocene paleogeography of the Mulegé embayment. Present day coastline shown as a solid line, and late Pliocene shoreline shown as dashed. See text for discussion.

Figura 3. Paleogeografía del área de Mulegé durante el Plioceno Tardío. La línea sólida, y la del Plioceno Tardío se muestra con la línea punteada. Ver discusión en el texto. 


\section{Late Pleistocene}

\section{Localities 3249, 3250, 3259 and 3263}

These localities contain faunal assemblages characteristic of an intertidal, slightly brackish, sand- and mud-flat paleonvironment. Genera at these localities characteristic of this biofacies include Chione, Cerithium, Oliva, and Tagelus.

The sediments comprising the terrace deposits at these localities consist of muddy sands, which support the interpretation of the depositional environment indicated by the fossil assemblages. At localities 3249, 3259, and 3263 individuals of Tagelus califomianus occur in living position, while paired valves of Chione and other bivalves are also present. Locality 3249 contains several genera (Crepidula, Crucibulum, Diodora, Hipponix) indicative of a rocky intertidal environment, indicating the presence of rocks nearby.

The area encompassing the $\mathrm{La}$ Serenidad airstrip localities was a shallow arm of the Mulegé estuary during the late Pleistocene. This area was probably surrounded by mangroves, as evidenced by the abundance of Ostrea at these localities (Fig. 4).

Locality 3259 was a bit further upstream than the La Serenidad airstrip localities but consisted of the same faunal assemblage with a muddy substrate fauna being slightly more abundant. This locality probably also had mangroves in close proximity to it, as evidenced by the abundance of Ostrea and carbonaceous material. Presently, mangrove trees line the margin of the estuary only $20 \mathrm{~m}$ from this locality and have abundant oysters growing on their roots.

The salinity of the water in the Mulege estuary during the late Pleistocene was slightly brackish. It was dominated by a marine influx at the La Screnidad airport localitics as well as locality 3259.3259 had slightly lower salinity, as suggested by the greater percentage of brackish water forms at this locality. Ostrea typically requires a slight fresh-water influx (Keen, 1971). However, the majority of rocas. Los fósiles encontrados en esta localidad incluyen Polinices sp., Chione califomiensis y Tagelus Califomianus. El género Polinices es generalmente un habitante de la arena intermareal. Tagelus califomianus y Chione califomiensis se encuentran en fondos poco profundos, lodosos a arenosos. Los fósiles en esta localidad no ocurren in situ; sin embargo se encuentran generalmente las dos valvas, lo que indica un transporte relativamente reducido. Esta área también fue probablemente un estuario como Mulegé durante el Plioceno tardio.

\section{Pleistoceno tardío}

$$
\text { Localidades 3249,3250,3259 y } 3263
$$

Estas localidades contienen ensamulajes faunales, característicos de un paleoambiente de planicie lodosa y arenosa, intermareal y ligeramente salina. Los gêneros presentes en estas localidades, característicos de esta biofacie incluyen Chione, Cerithium, Oliva y Tagelus.

Los sedimentos que componen los depósitos en terraza en estas localidades están constituidos por arenas lodosas, lo cual confirma la interpretación del ambiente depositacional indicado por los ensamblajes fósiles. En las localidades 3249,3259 y 3263 , se encuentran individuos de Tagelus califomianus en posición original, también las dos valvas de Chione y otros bivalvos. La localidad 3249 contiene varios géneros (Crepidula, Crucibulum, Diodora, Hipponix) indicadores de un ambiente intermareal rocoso, y por lo tanto de la existencia de rocas cercanas.

El área que comprende las localidades de la pista La Serenidad fue un brazo poco profundo del estuario Mulegé durante el Pleistoceno tardío. Esta área fue probablemente rodeada de mangles, como lo indica la abundancia de Ostrea en estas localidades (Fig. 4).

La localidad 3259 era ligeramente más agua arriba que las localidades de la pista $\mathrm{La}$ Serenidad pero se componía del mismo ensamblaje faunal con una fauna en substrato lodoso, ligeramente más abundante. Esta lo- 


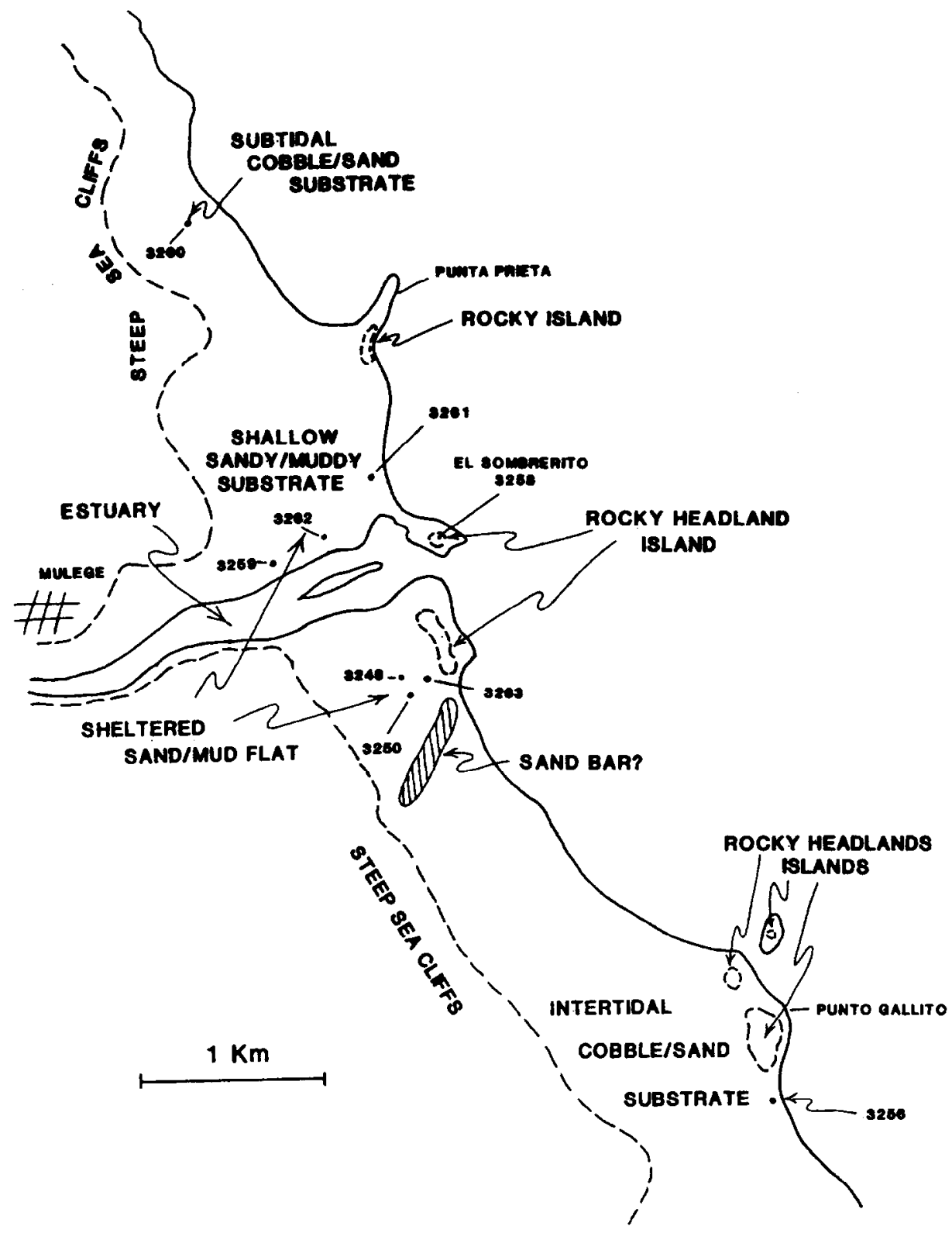

Figure 4. Paleogeography of the Mulegé embayment during the late Pleistocene $125 \mathrm{ka}-5 \mathrm{e}$ High Sea Stand. Present day coastline shown as a solid line, late Pleistocene shoreline shown as dashed. See text for discussion.

Figura 4. Paleogeografía del área de Mulegé durante el Pleistoceno Tardío 125 ka-5e High Sea Stand. La línea de costa actual se muestra como línea sólida, la del Pleistoceno Tardío como línea Punteada. Ver discusión en el texto. 
the fauna at these localities typically occur jusi inside the mouths of bays or estuaries. Such genera include Chione and Cerithum, which are found in abundance at all of these localities.

\section{Locality 3258}

Locality 3258 contains a fauna suggestive of two paleoenvironments. The first is a rocky intertidal to subtidal environment, and the second is a sand- and mud-flat environment. During the late Pleistocene El Sombrerito was surrounded by sand because the base level of the ancestral Mulegé river was much higher during the late Pleistocene than at present. Evidence for this is that remnants of estuarine muddy sandstone can still be observed in the crevasses along the terrace on $\mathrm{El}$ Sombrerito. El Sombrerito acted as a barrier to the late Pleistocene Mulegé estuary and had shells from the estuarine fauna accumulated around it as these shells were transported down the ancestral Mulegé river. Fauna indicative of the rocky intertidal environment at El Sombrerito consist of Turbo, Neorapana, Periglypta, and abundant sea urchin spines. Genera at this locality indicative of an estuarine environment are Cerithium, Glans, and Ostrea.

\section{Locality 3262}

Locality 3262 contains a faunal assemblage indicative of an intertidal to subtidal, sandy- to muddy-substrate environment. Genera indicative of this type of environment are Cerithium, Chione and Trachycardium.

This locality was a shallow, subtidal mud- to sand-flat behind a tombolo which extended south across the mouth of the Mulegé river to $\mathrm{El}$ Sombrerito. After the Holoceneerosion of this sand bar, only a small hill on the northern side of the estuary remained to indicate its former higher existence. This remnant of the sand bar comprises locality 3262 . Presently there is a tombolo at this same location forming the same environment; however, it is at a lower elevation.

Evidence of the late Pleistocene sand bar is in large part eroded, but the mixture of several offshore species in the fauna at locality calidad tambrén tenía probablemente mangles muy cerca, tal y como lo indica la abundancia de Ostrea y de material carbonoso. Actualmente, los mangles crecen en la orilla del estuario a solamente $20 \mathrm{~m}$, de esta localidad con abundantes ostiones sobre sus raices.

Las aguas en el estuario Mulegé eran ligeramente salinas durante el Pleistoceno tardío. El estuario fue dominado por una entrada de agua marina en las localidades del aeropuerto La Serenidad así como en la localidad 3259. Esta última tenía una salinidad ligeramente menor según lo sugerido por el mayor porcentage de formas de agua salina en esta localidad.Ostrea requiere un ligero influjo de agua dulce (Keen, 1971). Sin embargo, la mayor parte de la fauna en estas localidades ocurre típicamente justo dentro de la boca de las bahías o estuarios. Tales géneros incluyen Chione y Cerithium.

\section{Localidad 3258}

La localidad 3258 contiene una fauna que indica dos paleoambientes. El primero es un ambiente intermareal rocoso a submareal y el segundo es un ambiente de planicie arenoso a lodoso. Durante el Pleistoceno, El Sombrerito estaba rodeado por arena ya que el nivel de base del antiguo río Mulegé era mucho más alto durante el Pleistoceno tardío que hoy en día. La prueba de ello es que los restos de arenisca lodosa estuarina se pueden observar todavía en las grietas a lo largo de la terraza en El Sombrerito. El Sombrerito actuó como barrera en el estuario Mulegé del Pleistoceno tardío y conchas de fauna estuarina se acumularon a su alrededor, transportadas por el antiguo río Mulegé. La fauna indicadora del ambiente intermareal rocoso en El Sombrerito se compone de Turbo, Neorapana, Periglypta y abundantes espinas de erizos marinos. En esta localidad, los géneros que indican un ambiente estuarino son Cerithium, Glans y Ostrea.

\section{Localidad 3262}

La localidad 3262 contiene un ensamblaje faunal indicador de un ambiente submareal, de substrato arenoso a lodoso. Los géneros que indican este tipo de ambiente son Cerithium, Chione y Trachycandium. 
3262 suggests a moderate open marine influence at the time of deposition at this locality. Genera that indicate an exposed marine condition are Arca and Lyropecten. Genera indicative of the shallow, subtidal mud- to sand-flat environment are Cerithium, Ostrea, Trachycardium and Chione. This locality represented the back side of a foreshore sand bar with an esturine fauna living behind it, dominantly influenced by estuarine conditions with a slight influence from open marine waters.

\section{Locality 3261}

Locality 3261 contains a fauna indicative of a sand- to mud-flat environment bordered by a rocky area. Genera that indicate a sand- to mud-flat type of environment are Cerithidea, Chione, and Ostrea. General indicative of a rocky intertidal environment are Trimusculus and Turbo. This mixture of different faunal assemblages is consistent with the location of this locality in relation to 3262 , which is a sandy to muddy environment and to Punta Prieta which is a prominent rocky headland. During the late Pleistocene this locality consisted of a shallow, intertidal mudand sand-flat that received shells from nearby, rocky Punta Prieta as well as the fauna which was living in this immediate area.

\section{Locality 3260}

Locality 3260 contains a faunal assemblage indicative of a slightly offshore, cobble and sand substrate. Genera suggestive of this environment are Conus, Dosinia, and Hipponix, which suggest a rocky substrate in addition to Polinices and Fusinus, which indicate a sandy substrate. This environment was probably very similar to the modern environment. Presently this area of the coast contains well-rounded cobbles that are in places covered by sand, giving shelter to a mixture of sandy- and rocky- substrate dwellers. The sediments at this locality also suggest this type of environment. A basal conglomerate is covered by terrace sandstones, which contain the abundance of the fossils. The same species can be found both on the beach and in the late Pleistocene terrace deposits.
Esta localidad fue una planicie submareal poco profunda lodosa a arenosa detrás de un tómbolo que se extendía hacia el sur en la boca del río Mulegé hasta El Sombrerito Después de la erosión de este bajío de arena durante el Oloceno, sólo quedó un pequeño cerro en el lado norte del estuario indicando su existencia anterior más alta. El resto de este bajío de arena comprende la localidad 3262 . Actualmente, un tómbolo en este lugar forma el mismo ambiente aunque su elevación es menor.

El bajio de arena del Pleistoceno tardio está en gran parte erosionado, pero la presencia de varias especies de mar abierto en la fauna de la localidad 3262 sugiere una influencia marina moderada en el momento de la depositación en esta localidad. Los géneros que indican una condición de exposición marina son Arca y Lyropecten. Los géneros que indican un ambiente submareal poco profundo de planicie lodosa a arenosa son Cerithium, Ostrea, Trachycardium y Chione. Esta localidad representó el lado posterior de un banco de arena con una fauna estuarina, dominado por condiciones estuarinas con ligera influencia de las aguas del mar abierto.

\section{Localidad 3261}

La localidad 3261 contiene fauna indicadora de un ambiente de planicie arenosa a lodosa, rodeado de una zona rocosa. Los géneros que indican un tipo de ambiente de planicie arenosa a lodosa son Cerithidiea, Chione y Ostrea. Los géneros que indican un ambiente intermareal rocoso son Trimusculus y Turbo. Esta mezcla de diferentes ensamblajes faunales es consistente con la ubicación de esta localidad en relación con 3262 , que presenta un ambiente arenoso a lodoso y con Punta Prieta, promontorio rocoso. Durante el Pleistoceno tardio, esta localidad se componía de una planicie lodosa a arenosa intermareal y poco profunda, que recibía conchas de Punta Prieta, cercana y rocosa, así como fauna que vivía en los alrededores.

\section{Localidad 3260}

La localidad 3260 contiene un ensamblaje fauna indicador de un substrato de arena y de grava ligeramente alejado de la costa. Los 
Locality 3256

Locality 3256 contains a fauna that indicates an intertidal sandy substrate that was near a rocky area. Genera that indicate this type of environment are Polinices and Arca, which indicate a sandy substrate, and Hipponix, Turbo, sea urchin spines, and crab claws, which indicate a proximal rocky environment. This locality was located very near Punta Gallito, which was a rocky headland, and at the mouth of what was an embayment. It would be expected to contain a mixture of different faunas. The faund also consists of a small percentage of Ostrea, which were probably trancported from the shallow-water embayment that existed on the back side of Punta Gallito during the late Pleistocene.

\section{SUMMARY AND CONCLUSIONS}

Through the analysis of fossil molluscan taxa it is possible to partially reconstruct the paleogeography during the late Plic.cene and late Pleistocene in the area of Mulegé (Figs. 3 $\& 4)$. The presence of these shallow water marine environments both Pliocene and Pleistocene so near their present day counterparts indicates a lack of significant post late Pliocene tectonism in the coastal Mulegé area. The dating of the late Pleistocene terrace at $+12 \mathrm{~m}$ gives an indication of how little this isostatic uplift has been. This observation is rather significant in that only $50 \mathrm{~km}$ North, at Santa Rosalia Pleistocene terraces have been uplifted to as much as $+340 \mathrm{~m}$. It is clear that the same dramatic tectonic activity that has affected the Santa Rosalía area did not affect the Mulegé area.

\section{ACKNOWLEDGMENTS}

The authors wish to thank Thomas A. Demere of the San Diego Museum of Natural History, who offered many helpful suggestions and also reviewed this paper. Special thanks go to Dr. Richard $\mathrm{Ku}$ of the University of Southern California, who obtained uranium-series dates for these terraces. Also to Tom and Francis Baldwin who were the epitome of hosts at their home in Mulegé, and made the stay during field work very comfortable. géneros que indican este ambiente son Conus, Dosinia y Hipponix, los cuales sugieren un substrato rocoso mientras que los Polinices y Fusinus implican un substrato arenoso. Este ambiente fue probablemente muy similar al ambiente moderno. Actualmente esta área de la costa contiene grava muy redondeada, que en algunos lugares cstá cubierta por arena y constituye el habitat de una serie de moradores del substrato rocoso y arenoso. Los sedimentos en esta localidad también sugieren este tipo de ambiente. Un conglomerado de base está cubierto por arenisca en terrazas, que contiene gran cantidad de fósiles. Se pueden encontrar las mismas especies en la playa así como en los depósitos en terraza del Pleistoceno tardío.

\section{Localidad 3256}

La localidad 3256 contiene una fauna indicadora de un substrato arenoso intermareal que se encontraba cerca de un área rocosa. Los géneros que indican este tipo de ambiente son Polinises y Arca que sugieren un substrato arenoso,e Hipponix, Turbo, espinazos de erizos del mar y pinzas de cangrejo, que implican un ambiente rocoso próximo. Esta localidad estaba situada muy cerca de Punta Gallito, promontorio rocoso,y en la boca de lo que fue una ensenada. Podría contener una mezcla de faunas diferentes. La fauna también consiste en un pequeño porcentaje de Ostrea, que probablemente fue transportado de la ensenada poco profunda que existía atrás de Punta Gallito durante el Pleistoceno tardío.

\section{RESUMEN Y CONCLUSIONES}

Mediante el análisis de la taxonomía de los moluscos fósiles, es posible reconstruir parcialmente la paleongeografía durante el Plioceno tardío y el Pleistoceno tardio en el área de Mulegé (Figs. 3 y 4). La presencia de estos ambientes marinos de agua poco profunda del Plioceno y del Plcistoceno tan cercanos de sus contrapartes actuales indica la ausencia de un tectonismo del Plioceno postardio significativo en el área costero de Mulegé. La datación de la terraza del Pleistoceno tardío a $+12 \mathrm{~m}$ indica esta poca elevación isostática. Esta observación es bastante significativa en el sentido de que sólo a $50 \mathrm{~km}$ al norte, en Santa 


\section{LITERATURE CITED}

Anderson, CA. (1950) 1940 E.W. Scripps cruise to the Gulf of California, part 1, Geology of islands and neighboring land areas: Geol. Soc. America, Mem. 43, 53 p.

Ashby, J.R., Ku, T.L., and Minch, J.A., in press, Uranium series age of corals from the upper Pleistocene Mulegé Terrace, Baja California Sur, México: Geology, vol. 15, no. 2?

Beal, C.H. (1948) Reconnaissance of the geology and oil possibilities of Baja California, México: Geol. Soc. America, Mem. 31, 138 p.

Bender, M.L., Fairbanks, R.G., Taylor, F.W., Mathews, R.K., Goddard, J.G. and Broecker, W.S. (1979) Uranium-series dating of the Pleistocene reef tracts of Barbados, West Indies: Geol. Soc. America Bull., v.90, p. 577-594.

Durham, J.W. (1950) 1940 E.W. Scripps cruise to the Gulf of California, part 2, Megascopic paleontology and marine stratigraphy: Geol. Soc. America, Mem. 43, 216 p.

Gabb, W.M. (1867) Geol. Survey California, Reports, v. 2. in Browne, J.R. (1869). Mineral resources of the States and Territories west of the Rocky Mountains: resources of the Pacific slope, New York, p. 137-148.

Keen, M.A. (1971) Sea shells of tropical west america: Stanford Univ. Press, Stanford, California, $624 \mathrm{p}$.

Mathews, R.K. (1973) Relative elevation of late Pleistocene high sea level stands: Barbados uplift rates and their implications: Quat. Res., v. 3, p. 147-153.

McFall, C.C. (1968) Reconnaissancegeology of the Concepción Bay area, Baja California, México: Stanford University Pubs. in Geol. Sciences, v. 10, no. 5, 25 p., 3 plates.
Rosalía, terrazas del Pleistoceno han sido elevadas hasta $+340 \mathrm{~m}$. Está claro que el área de Mulegé no fue afectado por la misma actividad tectónica considerable que la que afectó Santa Rosalia.

\section{AGRADECIMIENTOS}

Los autores desean expresar su gratitud a Thomas A. Demere del Museum of Natural History de San Diego, quien ofreció muchas sugerencias útiles y revisó este trabajo. También agradecemos particularmente al Dr. Richard $\mathrm{Ku}$ de la University of Southern California, quien obtuvo las dataciones con uranio para estas terrazas. Asimismo, queremos agradecer a Tom y Francis Baldwin quienes ofrecieron su gran hospitalidad $y$ permitieron así una muy confortable estancia durante el trabajo de campo.

Ortleib, L. (1978) Reconocimiento de las terrazas marinas cuaternarias en la parte central de Baja California: Univ. Nat. Auto. México. Inst. Geología, revista, v.2, núm.2, p.200-211.

Shakleton, N.J. and Opdyke, N.S. (1973) Oxygen isotope and paleomagnetic stratigraphy of equatorial Pacific core V28-238: Oxygen isotope temperatures and ice volume on a 10 and 10 year scale: Quat. Res. v. 3, p. 39-55.

Sterns, C.E. (1976) Estimates of the position of sea level between 145,000 and 75,000 years ago: Quat. Res. v. 6, 445-449.

Wilson, I.F., (1948) Buried topography, initial structures, and sedimentation in the Santa Rosalía area, Baja California, México: Am. Assoc. Petroleum Geologists Bull., V.32, 1762-1807 p.

Wilson, I.F. and Rocha, V.S. (1955) Geology and mineral depostis of the Boleo copper district Baja California, México: Geol. Survey Professional Paper 273, 134 p. 